\title{
PENGARUH KONSELING INDIVIDUAL TEKNIK SELF CONTROL TERHADAP GAYA HIDUP KONSUMTIF PADA SISWA KELAS XI SMA HARAPAN 1 MEDAN T.A 2017/2018
}

\author{
Tri Wulandari \\ Dra. Zuraida Lubis, M.Pd, Kons \\ Program Studi BK FIP Universitas Negeri Medan
}

\begin{abstract}
Abstrak
Tujuan penelitian ini adalah untuk mengetahui pengaruh konseling individual teknik self control terhadap gaya hidup konsumtif pada siswa kelas XI SMA Harapan 1 Medan TA 2017/2018. Metode yang digunakan dalam penelitian ini adalah metode kuantitatif.Jenis penelitian ini adalah pra eksperimen dengan desain one group pre-test dan post-test design.Subjek dalam penelitian ini adalah siswa kelas XI yang terdiri dari 4 orang siswa. Instrument yang digunakan adalah skala untuk mengetahui gaya hidup konsumtif siswa. Instrument diberikan sebelum dan sesudah pelaksanaan konseling individual teknik self control. Teknik analisis data yang diperoleh menggunakan Uji Wilcoxon.Hasil analisis data yang diperoleh dalam penelitian ini adalah nilai $J_{\text {hitung }}=3$ dengan $\alpha=0,05$ dan $n=4$, maka berdasarkan daftar, $J_{\text {tabel }}=0$. Dengan demikian $J_{\text {hitung }}>J_{\text {tabel }}(3>0)$ ). Data Pre-test diperoleh rata - rata 156 termasuk kategori tinggi sedangkan data posttest atau setelah pemberian layanan konseling individual teknik self control diperoleh skor rata-rata 97 termasuk kategori rendah. Artinya rata - rata siswa setelah mendapat layanan konseling individual dengan teknik self control lebih rendah daripada sebelum mendapat layanan konseling individual dengan teknik self control. Perubahan penurunan interval gaya hidup konsumtif siswa setelah diberi layanan konseling individual dengan teknik self control sebesar 37,82\%. Hal ini menunjukan ada pengaruh pemberian konseling individual dengan teknik self control terhadap gaya hidup konsumtif siswa kelas XI SMA Harapan 1 Medan T.A 2017/2018 atau hipotesis diterima.

Kata kunci: Konseling Individual; Teknik Self Control; Gaya Hidup Konsumtif
\end{abstract}

\section{PENDAHULUAN}

Sarwono (2005:107) menyatakan bahwa remaja di kota besar memiliki akses terhadap informasi yang lebih besar daripada remaja di daerah. Remaja sering dijadikan target bagi pemasaran berbagai produk industri karena mereka memiliki karakteristik yang labil, spesifik dan mudah dipengaruhi sehingga akhirnya mendorong munculnya berbagai gejala dalam perilaku yang tidak wajar. Alasannya karena mereka sedang mengikuti arus mode dan tren, hanya ingin mencoba produk baru, dan ingin memperoleh pengakuan sosial di lingkungannya.Di dalam perkembangan remaja, teman sebaya merupakan pengaruh signifikan terhadap gaya hidup remaja, karena apabila remaja tidak mengikuti trend yang ada di dalam kelompoknya maka remaja akan di anggap ketinggalan zaman dan berbeda dengan kelompoknya. Untuk itu, remaja cenderung mengikuti aturan yang ada di dalam kelompok dengan tujuan agar tidak terdapat perbedaan di dalam kelompoknya.

Kelompok teman sebaya membantu mereka belajar bagaimana hidup bersama, memahami seberapa pintar dan seberapa disukainya mereka.Kelompok teman sebaya cenderung terdiri dari satu 
jenis kelamin, memungkinkan remaja belajar dan berperilaku sesuai dengan gendernya (Papalia, Diane E. dkk, 2008:505). Sebagian besar remaja membeli barang hanya untuk memperoleh pengakuan dari orang lain tanpa pertimbangan yang rasional. Dengan kata lain, remaja cenderung membeli barang-barang yang tidak dia butuhkan secara berlebihan hanya untuk memenuhi keinginan sesaatnya dan mendapatkan pengakuan di lingkungan kelompok teman sebayanya.

Kebutuhan untuk diterima dan menjadi sama dengan orang lain yang sabaya itu menyebabkan remaja untuk mengikuti berbagai atribut yang sedang popular. Salah satu caranya adalah dengan gaya hidup konsumtif, seperti memakai barang-barang yang baru dan bermerk, pergi ke tempat-tempat mewah secara rutin untuk bersenang-senang seperti pergi ke restoran,cafe,dan tempat lainnya. Kebiasaan seperti ini menjadikan remaja memiliki gaya hidup yang konsumtif.

Menurut Zebua dan Nurdjayadi (2001), perilaku konsumtif menggambarkan suatu tindakan yang tidak rasional dan bersifat kompulsif sehingga secara ekonomis menimbulkanpemborosan dan inefisiensi biaya.Individu dengan tindakan tidak rasional dankompulsif selalu merasa belum lengkap dan mencari kepuasan dengan membeli barang-barang yang baru.Hadipranata (dalam Nashori.1991) mengamati bahwa wanita mempunyai kecenderungan lebih besar untuk berperilaku konsumtif dibanding pria.Hal ini disebabkan konsumen wanita cenderung lebih emosional sedang konsumen pria lebih nalar.Remaja putri cenderung merasa kurang puas dengan penampilan maupun fisiknya dan senantiasa membandingkan antara dirinya dengan teman sebayanya.Hal ini menjadikan remaja semakin sulit membedakan antara kebutuhan dan keinginannya demi menjaga gengsi dalam pergaulannya.

Gaya hidup konsumtif tidak dapat dibiarkan secara terus-menerus di kalangan remaja atau siswa karena hal ini akan membiasakan dirinya untuk berperilaku yang negatif terhadap dirinya maupun orang lain. Perilaku negatif yang terjadi pada siswa yang memiliki gaya hidup konsumtif yaitu boros dalam hal membelanjakan barang-barang yang tidak dibutuhkannya.

Adler mengemukakan bahwa gaya hidupyang diikuti individu adalah kombinasi dari dua hal, yakni dorongan dari dalam diri (the inner self driven) yang mengatur arah perilaku, dan 
dorongan dari lingkungan yang mungkin dapat menambah, atau menghambat arah dorongan dari dalam tadi.

Menurut Kotler (2000), faktor yang mempengaruhi perilaku membeli yang memiliki andil dalam pembentukan perilaku konsumtif ada dua, yaitu faktor internal dan eksternal. Di dalam faktor internal terdapat faktor pribadi dan faktor psikologis, salah satu faktor internal terkait dengan usia yaitu remaja biasanya mudah terbujuk rayuan iklan dan cenderung boros dalam menggunakan uangnya.

Teknik self control dapat mengarahkan siswa mengendalikan diri untuk tidak mudah terpengaruh oleh bujukan iklan dan terhindar dari perilaku konsumtif.Dalam hal ini konseling individual dapat dilakukan oleh guru BK dalam memberikan bantuan kepada individu untuk mengembangkan kesehatan mental, perubahan sikap, dan tingkah laku.

Dengan begitu, layanan konseling individual dengan teknik self control dapat digunakan untuk mencegah gaya hidup konsumtif pada siswa.

Berdasarkan hasil observasi dan wawancara yang dilakukan pada tanggal dengan guru BK SMA Swasta Harapan 1 Medan maka didapatkan pernyataan bahwa terdapat siswa yang memiliki gaya hidup konsumtif di sekolah tersebut.

Melalui wawancara yang dilakukan dengan beberapa siswa didapatkan pernyataan bahwa rata-rata siswa mendapatkan uang saku sebesar Rp 50.000 - Rp 100.000 perharinya. Uang saku sebesar Rp 100.000 dipergunakan siswa untuk biaya ongkos pergi dan pulang sebesar Rp 20.000 dan untuk uang makan sebesar 25.000 dengan waktu pulang sekolah pukul 14.00. Maka sisa dari uang saku siswa dapat dipergunakannya untuk hal-hal yang dianggapnya menyenangkan meskipun tidak di butuhkannya. Dengan uang saku yang cukup tinggi untuk kalangan siswa SMA maka hal tersebut dapat meningkatkan gaya hidup konsumtif pada siswa.

\section{KAJIANPUSTAKA}

Remaja yang sedang berada dalam masa peralihan dari masa kanak kanak dengan suasana hidup penuh ketergantungan pada orang tua menuju masa dewasa yang bebas, mandiri dan matang (Santrock, 2003).Termasuk bagaimana remaja terutama remaja putri berusaha menampilkan diri secara fisik, hal ini agar sesuai dengan komunitas mereka. Atau bisa juga dengan pengaruh iklan, karena akan timbul keinginan untuk berbelanja seperti halnya iklan 
yang ditayangkan di televisi. Keinginan ini mendorong remaja untuk cenderung berperilaku konsumtif.

Pribadi dalam wawancara antara seorang konselor dan seorang konseli (siswa). Konseli mengalami kesukaran pribadi yang tidak dapat ia pecahkan sendiri, kemudian ia meminta bantuan konselor sebagai petugas yang profesional dalam jabatannya dengan pengetahuan dan keterampilan psikologi. Konseling ditujukan kepada individu yang normal, yang menghadapi kesukaran dalam masalah pendidikan, pekerjaan, dan sosial dimana ia tidak dapat memilih dan memutuskan sendiri. Oleh karena itu, konseling hanya ditujukan kepada individu-individu yang sudah menyadari kehidupan pribadinya.

$$
\text { Dalam konseling terdapat }
$$
hubungan yang dinamis dan khusus, karena dalam interaksi tersebut, konseli merasa diterima dan dimengerti oleh konselor. Dalam hubungan ini, konselor dapat menerima konseli secara pribadi dan tidak memberikan penilaian. Konseli merasa ada orang lain yang dapat mengerti masalah pribadinya dan mau membantu memecahkannya. Konselor dan konseli saling belajar dalam pengalaman hubungan yang bersifat khusus dan pribadi ini.(Juntika Nurihsan, $2005: 10)$
Pengertian konseling individual mempunyai makna spesifik dalam arti pertemuan konselor dengan klien secara individual, dimana terjadi hubungan konseling yang bernuansa rapport, dan konselor berupaya memberikan bantuan untuk pengembangan pribadi klien serta klien dapat mengantisipasi masalahmasalah yang dihadapinya. Bimbingan untuk pengembangan potensi klien agar mencapai taraf perkembangan yang optimal. Proses bimbingan dan konseling berorientasi pada aspek positif artinya selalu melihat klien dari segi positif (potensi, keunggulan) dan berusaha menggembirakan klien dengan menciptakan situasi proses konseling yang kondusif untuk pertumbuhan klien.

Konseling individual adalah kunci semua kegiatan bimbingan dan konseling. Karena jika menguasai teknik-teknik konseling individual berarti akan mudah menjalankan proses bimbingan dan konseling. Karena itu kepada calon konselor disarankan agar menguasai proses dan teknik konseling individual. Proses konseling individual merupakan relasi antara konselor dengan klien dengan tujuan agar dapat mencapai tujuan klien. Dengan kata lain tujuan konseling tidak lain adalah tujuan klien itu sendiri. Sofyan S. Willis (2014 : 159)

Tujuan umum layanan konseling 
individual adalah terentaskannya masalah yang dialami konseli. Apabila masalah konseli itu dicirikan antara lain: sesuatu yang tidak disukai adanya, suatu yang ingin dihilangkan, sesuatu yang dapat menghambat atau menimbulkan kerugian, maka upaya pengentasan masalah konseli melalui konseling individual akan mengurangi intensitas ketidaksukaan atas keberadaan atas sesuatu yang di maksud. Dengan layanan konseling individual beban konseli diringankan, kemampuan konseli ditingkatkan, dan potensi konseli dikembangkan.

Prayitno (2004: 4) menyatakan bahwa tujuan umum layanan konseling perorangan adalah pengentasan masalah klien dan hal ini termasuk kedalam fungsi pengentasan. Lebih lanjut Prayitno mengemukakan tujuan khusus konseling ke dalam lima hal yakni fungsi pemahaman, fungsi pengentasan, fungsi pengembangan, fungsi pencegahan, dan fungsi advokasi.

Dalam penyelenggaraan pelayanan bimbingan dan konseling kaidah-kaidah dikenal dengan azas-azas bimbingan dan konseling, yaitu ketentuan-ketentuan yang harus diterapkan dalam penyelenggaraan pelayanan itu. Apabila azas-azas itu diikuti dan terselenggara dan terselenggara dengan baik sangat dapat diharapkan proses pelayanan mengarah pada pencapaian tujuan yang diharapkan. Sebaliknya, apabila azas-azas itu diabaikan atau dilanggar sangat dikhawatirkan kegiatan yang terlaksana itu justru berlawanan dengan tujuan bimbingan dan konseling.

Azas-azas yang dimaksudkan adalah azas kerahasiaan, kesukarelaan, keterbukaan, kekinian, kemandirian, kegiatan, kedinamisan, keterpaduan, kenormatifan, keahlian, alih tangan, dan tut wuri handayani (Prayitno, 1987).Dalam menyelenggarakan pelayanan bimbingan dan konseling di sekolah hendaknya selalu mengacu pada azas-azas bimbingan dan konseling dan diterapkan sesuai dengan azas-azas bimbingan konseling.Azas-azas ini dapat dianggap sebagai suatu rambu-rambu dalam pelaksanaan bimbingan dan konseling.

Pada tahap awal konseling menurut Willis (2014 : 239 ) tahap ini disebut juga tahap defenisi masalah karena tujuannya adalah supaya pembimbing bersama klien mampu mendefinisikan masalah klien yang ditangkap atau dipilih pesan klien dalam dialog konseling itu. Dalam hal ini strategi self control yang dapat digunakan dalam konseling yaitu konselor meminta agar klien memikirkan konsekuensi yang akan dihadapinya jika gaya hidup konsumtif terus-terusan 
menjadi kebiasaan dalam hidupnya. Pada tahap pertengahan disebut tahap kerja yang bertujuan untuk mengelolah atau mengerjakan masalah klien, di tahap ini teknik self controlyang dilakukan yaitu klien diminta untuk menanyakan pada dirinya faktor-faktor apa yang menjadi penyebab dirinya memiliki gaya hidup konsumtif dan apa dampaknya. Di tahap akhir konseling individual disebut tahap tindakan (action) bertujuan agar klien mampu menciptakan tindakan-tindakan positif seperti perubahan perilaku dan emosi serta perencanaan hidup masa depan yang positif setelah dapat mengatasi masalahnya. Pada tahap ini klien telah memiliki perencanaan positif yang akan dilakukannya dalam mengendalikan dirinya dari gaya hidup konsumtif.

Kerangka pemikiran dalam penelitian ini adalah bahwa layanan konseling individual teknik self control berpengaruh pada gaya hidup konsumtif peserta didik. Karena penggunaan teknik self control dapat membantu peserta didik untuk lebih pandai mengendalikan dirinya agar gaya hidup konsumtif menurun.

\section{METODE PENELITIAN}

\section{Jenis Penelitian}

Jenis dari penelitian ini adalah jenis penelitian pra eksperimental yaitu penelitian yang memberikan perlakuan atau tindakan kepada sekelompok orang atau subjek penelitian dengan pendekatan kuantitatif.Adapun desain pre test dan post test group design. Penelitian ini dilakukan pada siswa kelas XI MIA 3 SMA Harapan 1 Medan TA 2017/2018 sebanyak 30 orang, yang terdiri dari 13 siswa perempuan dan 17 siswa laki-laki. Subjek penelitian ini adalah 4 orang siswa, yang telah diseleksi merupakan siswa-siswi yang mempunyai gaya hidup konsumtif tinggi.

Sebelum dan sesudah eksperimen dilakukan, beberapa varian yang dikontrol dalam penelitian ini adalah internal varian dan eksternal varian. Beberapa ancaman terhadap validitas internal adalah : 1) Karakteristik subjek, 2) Hilangnya subjek (mortality), 3) Lokasi, 4) Instrumentasi (implementer effect), (5) Testing, (6) Sejarah (history), (7) Kematangan (maturity), 8) Sikap subjek, (9) Regresi statistik, 10) Implementasi (implementer effect).Beberapa ancaman terhadap validitas eksternal adalah: 1) Interaksi antar seleksi subjek dan perlakuan, 2) Interaksi setting dengan perlakuan, 3) Interaksi sejarah dengan perlakuan. Menanti (2014: 45-65).

Adapun instrumen yang digunakan untuk mengumpulkan data dalam 
penelitian ini adalah angket (kuesioner). Angket yang dibuat bersifat skala ordinal yang berpedoman pada skala likert yang terdiri dari 4 alternatif jawaban yaitu Sangat sering (SS), Sering (S), Kadangkadang (KK), Tidak pernah (TP). Skala likert memiliki sifat Favourable (mendukung pernyataan/ positif) dan unfavourable (tidak mendukung pernyataan/ negatif) Adapun yang bersifat positif diberi rentangan nilai 4-1 sedangkan yang bersifat negatif diberi rentangan nilai 1-4.

Adapun teknik analisis data yang digunakan dalam penelitian ini adalah dengan menggunakan Wilcoxon, uji satu pihak "testranking- bertanda Wilcoxon" yaitu dengan mencari perbedaan meanpretest dan posttest.

Untuk menguji hipotesis di atas dengan taraf nyata $\alpha=0,01$ atau $\alpha=0,05$, bandingkan $\mathbf{J}$ di atas dengan $\mathbf{J}$ yang diperoleh dari daftar tabel uji wilcoxon. Jika $\mathrm{J}$ dari perhitungan lebih kecil atau sama dengan $\mathbf{J}$ dari daftar tabel uji wilcoxon, maka $\mathrm{H}_{0}$ ditolak dan sebaliknya, apabila $\mathbf{J}$ dari perhitungan lebih besar dari daftar tabel uji Wilcoxon maka $\mathrm{H}_{0}$ di terima.

HASIL PENELITIAN DAN PEMBAHASAN

Data dalam penelitian ini diperoleh dengan melakukan pengukuran pada gaya hidup konsumtif siswa dengan melakukan observasi dan menyebarkan angket sebelum pemberian layanan konseling individual teknik self control, selanjutnya data-data ini diolah dengan tahapan: mendeskripsikan data, menguji persyaratan analisis, dan menguji hipotesis.

Uji validitas kepada 30 orang siswa kelas XI MIA 4. Setelah melakukan validitas skala, diadakan pelaksanaan pre-test kepada siswa kelas XI MIA 3 untuk mengetahui gaya hidup konsumtif siswa sebelum mendapatkan layanan konseling individual dengan teknik self control. Berdasarkan hasil analisis pre-test skala skor tentang gaya hidup konsumtif siswa, diperoleh 4 sampel dalam penelitian ini dengan kriteria skor gaya hidup konsumtif tinggi.

Berdasarkan jumlah skor pre-test 624 dan skor post-test 388 maka selisih skor berjumlah 236 dengan persentase 37,82. Adapun skor tertinggi pada pretest yaitu 167 dan skor tertinggi post-test yaitu 99 maka selisih skor berjumlah 68 dengan persentase 40,71 dan skor terendah pada pre-test yaitu 150 dan skor terendah post-test yaitu 94 maka selisih skor berjumlah 52 dengan persentase 34,66 . Dengan demikian maka diperoleh skor rata-rata pre-test 156 dan skor rata- 
rata post-test 97 maka selisih skor ratarata 59 dengan persentase 37,82 .

Berdasarkan hasil penelitian ini, bahwa hipotesis penelitian diterima, artinya terdapat pengaruh dari layanan konseling individual teknik self control terhadap gaya hidup konsumtif siswa kelas XI SMA Harapan 1 Medan tahun ajaran 2017/2018. Hal ini telah ditunjukkan dari hasil perhitungan uji Wilcoxon yaitu $\mathbf{J}_{\text {hitung }}>\mathbf{J}_{\text {Tabel }}=\operatorname{dimana} 3>$ 0. Berdasarkan analisis secara keseluruhan pada 4 orang responden terjadi penurunan gaya hidup konsumtif, dari hasil tersebut dapat dilihat pada tes awal (pre-test) diperoleh skor rata-rata gaya hidup konsumtif siswa= 156 dan setelah pemberian layanan konseling individual teknik self control (post-test) diperoleh $=97$ maka selisih skor rata-rata 59 dengan persentase 37,82 artinya ratarata skor gaya hidup konsumtif lebih tinggi sebelum mendapatkan layanan konseling individual teknik self control, dan setelah diberikan layanan konseling individual teknik self control maka gaya hidup konsumtif menjadi menurun (rendah).

Namun demikian masih ditemukan responden yang memiliki perubahan yang kecil yaitu R4, dimana hasil pre-test memperoleh skor 155 dan hasil post-test memperoleh skor 94 maka selisih skor 61 dengan persentase hanya 39,35, artinya responden $\mathrm{R} 4$ memperoleh skor dalam kategori tinggi sebelum mendapatkan layanan konseling individual teknik self control, dan setelah diberikan layanan konseling individual teknik self control memperoleh skor dalam kategori rendah, namun hasil perubahan skor sebelum dan sesudah mendapatkan layanan konseling individual teknik self control hanya sedikit terjadi penurunan.Hal ini disebabkan bahwa R4 kurang bertanggung jawab dalam melaksanakan jadwal kegiatan yang telah disepakati, terdapat beberapa kegiatan yang tidak terlaksana dengan baik oleh R4. Berdasarkan laiseg yang telah di isi terdapat pernyataan bahwa R4 merupakan seorang yang sulit dalam menahan diri untuk tidak membeli barang-barang yang tidak R4 butuhkan.Sehingga penurunan hanya terjadi sedikit pada R4. Namun R4 menyadari akan hal itu, dari harapan maupun keinginan yang R4 nyatakan dalam laiseg, R4 berharap untuk bisa terus mengikuti kegiatan layanan konseling individual teknik self control ini seterusnya agar merubah gaya hidupnya menjadi lebih efektif.

Dari beberapa pendapat para ahli gaya hidup konsumtif merupakan tindakan individu untuk membeli atau mengkonsumsi barang atau jasa secara 
berlebihan yang bukan merupakan prioritas kebutuhannya dan tanpa pertimbangan yang rasional, demi kepuasan fisik dan dorongan untuk memuaskan hasrat kesenangan. Tambunan (2001) mendefinisikan perilaku konsumtif sebagai keinginan untuk mengkonsumsi barang-barang yang sebenarnya kurang diperlukan secara berlebihan untuk mencapai kepuasan yang maksimal.Menurut Zebua dan Nurdjayadi (2001), perilaku konsumtif menggambarkan suatu tindakan yang tidak rasional dan bersifat kompulsif sehingga secara ekonomis menimbulkan pemborosan dan inefisiensi biaya.Individu dengan tindakan tidak rasional dan kompulsif selalu merasa belum lengkap dan mencari kepuasan dengan membeli barang-barang yang baru.

Di dalam lingkungan sekolah gaya hidup konsumtif tidak dapat dibiarkan secara terus-menerus di kalangan remaja atau siswa karena hal ini akan membiasakan dirinya untuk berperilaku yang negatif terhadap dirinya maupun orang lain. Perilaku negatif yang terjadi pada siswa yang memiliki gaya hidup konsumtif yaitu boros dalam hal membelanjakan barang-barang yang tidak dibutuhkannya. Siswa cenderung menjadi seorang anak yang penuntut terhadap orang tua untuk dapat menuruti apa yang menjadi kehendaknya. Jika siswa di sekolah hanya berfokus untuk sekedar memamerkan barang-barang yang ia miliki dengan tujuan untuk mendapatkan pengakuan atas dirinya oleh temannya maka anak menjadi sombong dan tidak bersyukur atas apa yang dimilikinya sehingga prestasi belajarnya di sekolah juga akan menurun.

Konseling individual teknik self control merupakan salah satu upaya dalam meminimalisir gaya hidup konsumtif pada siswa di SMA Harapan 1 Medan. Konseling individual adalah proses belajar melalui hubungan khusus secara pribadi dalam wawancara antara seorang konselor dan seorang konseli (siswa). Konseli mengalami kesukaran pribadi yang tidak dapat ia pecahkan sendiri, kemudian ia meminta bantuan konselor sebagai petugas yang profesional.Teknik self controlmerupakan bantuan yang diberikan pada siswa untuk mengendalikan dirinya agar lebih bisa mengarahkan tindakannya, mampu membuat pertimbangan dan keputusan pada tugas yang seharunya dilakukan.

Ditinjau dari hasil laiseg ditemukan bahwa anggota kelompok sudah memiliki cara berfikir dan bersikap yang baik terhadap gaya hidup konsumtif mereka. Dengan demikian terlihat komitmen 
siswa dalam gaya hidup konsumtif yang dibuktikan dari hasil skala post-test yang diberikan peneliti yang menunjukkan penurunan gaya hidup konsumtif siswa. Bedasarkan pernyataan langsung yang di dapat dari siswa yang menyatakan bahwa ketika akan membeli barang siswa cenderung untuk memikirkan terlebih dahulu kegunaan dari barang yang akan dibelinya. Dengan begitu kegiatan layanan konseling individual teknik self control memberikan pengaruh terhadap gaya hidup konsumtif siswa.

\section{KESIMPULAN DAN SARAN}

\section{Kesimpulan}

Hasil analisis data yang diperoleh dalam penilitian ini adalah nilai $\mathbf{J}_{\text {hitung }}=3$ dengan $\alpha=0,05$ dan $n=4$ sehingga nilai $\mathrm{J}_{\text {tabel }}$ adalah 0. Dari data tersebut terlihat bahwa $\mathbf{J}_{\text {hitung }}>\mathrm{J}_{\text {tabel }}$ dimana $3>0$. Data pre-test atau sebelum pemberian layanan konseling individual teknik self control diperoleh skor rata-rata 156 sedangkan data post-test atau setelah pemberian layanan konseling individual teknik self control diperoleh skor rata-rata 97. Artinya skor rata-rata siswa setelah mendapat layanan konseling individual teknik self control lebih rendah daripada sebelum mendapat layanan konseling individual teknik self control. Perubahan penurunan interval gaya hidup konsumtif siswa setelah diberi layanan konseling individual teknik self control sebesar 236 dan rata-rata yang didapat setelah melakukan pre-test dan post-test adalah 59. Hal ini menunjukkan ada pengaruh pemberian layanan konseling individual teknik self control terhadap gaya hidup konsumtif siswa kelas XI MIA 3 SMA Harapan 1 Medan T.A 2017/2018 atau hipotesis dapat diterima.

\section{Saran}

Berdasarkan kesimpulan di atas, maka sebagai tindak lanjut penelitian ini disarankan hal-hal sebagai berikut :

1. Guru BK agar mempertimbangkan dan lebih mengembangkan program layanan konseling individual teknik self control dalam perubahan gaya hidup konsumtif siswa.

2. Diharapkan siswa lebih serius dalam mengikuti layanan-layanan bimbingan dan konseling di sekolah yang diberikan oleh guru BK, agar siswa dapat mengantisipasi permasalahanpermasalah sosial dan pribadinya.

3. Mengingat bahwa layanan konseling individual teknik self control dalam mengubah gaya hidup konsumtif, maka diharapkan kepala sekolah dapat terus mendukung para guru terutama guru BK dalam hal menjalankan layanan konseling individual teknik self control. 
4. Diharapkan sekolah berperan aktif dalam memfasilitasi kegiatan layanan bimbingan konseling di sekolah agar tujuan yang diharapkan lebih maksimal lagi.

5. Bagi orang tua diharapkan untuk tidak memberikan uang saku kepada siswa secara berlebihan, hanya sesuai dengan kebutuhannya saja. Agar siswa dalam menjalani hidupnya tidak memiliki gaya hidup konsumtif.

6. Bagi peneliti selanjutnya, semoga dapat menjadi bahan referensi dan menambah wawasan dalam melakukan penelitian selanjutnya, serta melakukan penelitian lebih lanjut tentang gaya hidup konsumtif.

\section{DAFTAR PUSTAKA}

Abu Ahmadi dan Cholid Norbuko. 2015. Metodologi Penelitian. Jakarta: Bumi Aksara.

Azwar, Saifuddin 2010. Sikap Manusia. Jogjakarta: Pustaka Pelajar.

Calhoun J.F dan Acocella, J.R. 1995.Psikologi Tentang Penyesuaian dan Kecemaan.Penerjemah. Satmiko S.R. Semarang : IKIP Press

Ghufron, Nur M dan Risnawati, Rini.2016.Teori-Teori Psikologi.Jogjakarta : Ar Ruzz Media.

Kotler, Philip dan Susanto. 2000. Manajemen Pemasaran di Indonesia. Jilid 1.Alih Bahasa Ancella A. Hermawan. Jakarta: Salemba Empat.
Kotler, Philip dan Keller, Kevin L. 2008.Manajemen Pemasaran. Jilid 1.AlihBahasaBenyamin Molan. Jakarta: P.T. Indeks.

Menanti, Asih. 2014. Penelitian Eksperimen. Medan: Penerbit Universitas Negeri Medan

Mubin dan Ani Cahyadi. 2006. Psikologi Perkembangan. Ciputat: Quantum Teaching

Nurihsan,Juntika. 2005. Strategi Layanan Bimbingan dan Konseling.Bandung : PT. Refika Aditama

Papalia, Diane E. dkk. 2008. Human Development (Psikologi Perkembangan). Jakarta : Kencana.

Prasetijo, Ristiayanti dan Ihalauw, John. 2005. Perilaku Konsumen. Jogjakarta:

Andi.

Prayitno.1995. Layanan bimbingan dan konseling kelompok.Jakarta : Ghalia Indonesia

Prayitno \& Amti E . 2004. Dasar-dasar Bimbingan dan Konseling.Jakarta : Rineka Cipta

Santrock, John W. 2003. Adolescence: Perkembangan Remaja. Alih Bahasa Shinto B. Adelar dan Sherly Saragih. Jakarta: Erlangga.

Sarwono, Sarlito Wirawan. 2005. Psikologi Sosial. Jakarta: Fajar Interpratama.

Sobur, Alex. 2003. Psikologi Umum. Bandung: C.V. Pustaka Setia.

Solomon, Michael R. 2007. Consumer Behavior: Buying, Having, and Being. 7th Edition. New Jersey: Pearson Education, Inc. 
Tambunan, Raymond. 2001. Remaja dan Perilaku

Konsumtif.Internet.http://epsikolo gi.com. Diakses 17 Maret 2011.

Tohirin. 2009. Bimbingan Dan Konseling Disekolah Dan Madrasah.Jakarta : PT Raja Grafindo Persada

Willis, Sofyan. 2014. Konseling Individual Teori dan Praktek. Bandung : CV Alfabeta

Zebua, Albertina S. dan Nurdjayadi, Rostiana D. 2001. Hubungan antara

Konformitas dan Konsep Diri dengan Perilaku Konsumtif pada Remaja Putri. Jurnal Phronesis. Vol. 3 No. 6, 72-82. 